\title{
Serotonergic Modulation of Striatal Dopamine Measured with Positron Emission Tomography (PET) and in vivo Microdialysis
}

\author{
Stephen L. Dewey, ${ }^{1}$ Gwenn S. Smith, ${ }^{2}$ Jean Logan, ${ }^{1}$ David Alexoff, ${ }^{1}$ Yu-Shin Ding, ${ }^{1}$ Payton King, ${ }^{3}$ Naomi \\ Pappas, ${ }^{3}$ Jonathan D. Brodie, ${ }^{2}$ and Charles R. Ashby, Jr. ${ }^{3}$ \\ 'Department of Chemistry, Brookhaven National Laboratory, Upton, New York 11973, 2Department of Psychiatry, New \\ York University School of Medicine, New York, New York 10016, and ${ }^{3}$ Medical Department, Brookhaven National \\ Laboratory, Upton, New York 11973
}

\begin{abstract}
Positron emission tomography and in vivo microdialysis were used to study serotonin's role in modulating striatal dopamine. Serial PET studies were performed in adult female baboons at baseline and following drug treatment, using the dopamine $\left(D_{2}\right)$ selective radiotracer, ${ }^{11} \mathrm{C}$-raclopride. The serotonergic system was manipulated by administration of the selective 5-HT reuptake inhibitor, citalopram, or by serotonergic $\left(5-\mathrm{HT}_{2}\right)$ receptor blockade (using altanserin, a $5-\mathrm{HT}_{2}$ antagonist). ${ }^{11} \mathrm{C}$-Raclopride time-activity data from striatum and cerebellum were combined with plasma arterial input functions and analyzed by calculating a distribution volume as described previously (Logan et al., 1990). Additionally, in vivo microdialysis studies were performed in awake freely moving rats using similar pharmacologic challenges plus SR 46349B, a new highly selective $5-\mathrm{HT}_{2}$ receptor antagonist. Altanserin and SR 46349B increased extracellular striatal dopamine concentrations (35\% and $910 \%$, respectively) while altanserin decreased striatal ${ }^{11} \mathrm{C}$-raclopride binding $(37 \%)$. Citalopram, however, decreased extracellular striatal dopamine concentrations (50\%) and increased ${ }^{11} \mathrm{C}$-raclopride binding $(33 \%)$. These data demonstrate that $5-\mathrm{HT}$ selective drugs produce changes in striatal dopamine that can be measured noninvasively with PET. Furthermore, the PET data obtained from anesthetized baboons is consistent with in vivo microdialysis data obtained from awake and freely moving rats. Finally, these studies have implications for understanding the therapeutic efficacy of atypical neuroleptics and their utility for treating schizophrenia and affective disorders.
\end{abstract}

[Key words: positron emission tomography, microdialysis, dopamine, 5-HT, interactions, raclopride]

\footnotetext{
Received Mar. 23, 1994; revised May 18, 1994; accepted July 18, 1994.

This work was carried out at Brookhaven National Laboratory under Contract DE-AC0276CH00016 with the U.S. Department of Energy (DOE) and supported by its Office of Health and Environmental Research. We also acknowledge support from the following Public Service Grants: NIMH, MH-49165 and MH-49936; NINDS NS-15380 and NS-15638. Further support of this work came as awards from the DOE Laboratory Directed Research and Developmental program to S.L.D. and awards from the National Alliance for Research on Schizophrenia and Depression (NARSAD) to S.L.D. and G.S.S. We gratefully acknowledge the assistance of Joanna S. Fowler, Alfred P. Wolf, S. John Gatley, Robert MacGregor, Colleen Shea, Tom Martin, Darrin Jenkins, David Schlyer, Don Warner, Clarence Barrett, and Robert Carciello. We thank Dr. Douillet from Sanofi Recherche, Inc., France, for the generous supply of SR 46349B and Dr. Hytell from H. Lunbeck A $/ S$ for the generous supply of citalopram.

Correspondence should be addressed to Stephen $\mathrm{L}$. Dewey at the above address. Copyright (c) 1995 Society for Neuroscience $0270-6474 / 95 / 150821-09 \$ 05.00 / 0$
}

Neurotransmitters interact in the CNS and PNS through an intricate network of efferent and afferent projections. Through these interactions, the CNS biochemically mediates the transfer of information from one specific neuroanatomic focus to another. By taking advantage of our fundamental knowledge of many of these pathways and their neurochemical interactions, we have been able to direct our neuroimaging positron emission tomography (PET) studies at the development of a methodology that can effectively be applied to an examination of these interactions in the living human brain (Dewey et al., 1988, 1993d). Previous studies from this laboratory demonstrate that PET can be used to measure the functional responsiveness of a neurotransmitter to a pharmacologic challengc. Furthermore, these findings suggest that PET can be applied to studying neurotransmitter interactions as well. For example, PET has been directed at measuring the ability of $\mathrm{ACh}, \mathrm{GABA}$, and the opiate system to modulate striatal dopamine (DA) release (Dewey et al., 1992a; Smith et al., 1993), and on the ability of GABA, 5-HT, and DA to modulate cortical and subcortical ACh (Dewey et al., 1990a, 1993b). These findings are consistent with data from other laboratories using traditional neuroanatomic and neurophysiologic approaches. Alterations in GABA, 5-HT, DA, opiates, and ACh have been implicated in the etiology and progression of many neuropsychiatric and neurologic diseases. Together these findings demonstrate that PET is well suited for studying neurotransmitter interactions and the consequences of their disruptions in normal volunteers. Future studies will be directed at investigations of these interactions in neurologic and psychiatric patients.

Given the demonstrated role of 5-HT/DA interactions in the mechanism of action of new antipsychotic and antidepressant compounds, the present study was specifically designed to characterize 5-HT's ability to modulate striatal DA activity. While this study provides a unique experimental approach, in terms of a noninvasive examination of this interaction with PET, extensive studies using a wide variety of neuroanatomic, neurophysiologic (including in vivo microdialysis), and behavioral techniques suggest that 5-HT's inhibitory or excitatory role in modulating striatal DA remains controversial (Fibiger and Miller, 1977; Waldmeier and Delini-Stula, 1979; Waldmeier, 1980; Sinton and Fallon, 1981; Quirion and Richard, 1985; Spampinato et al., 1985; Castrogiovanni et al., 1989; Sorensen et al., 1989; Benloucif and Galloway, 1991; Huang and Nichols, 1993). Many of these discrepancies may be attributed to species and experimental differences, variations in outcome measures, and differences in pharmacologic challenge conditions. Nonetheless, 
recent observations suggest that atypical neuroleptic drugs (drugs binding to both DA and 5- $\mathrm{HT}_{2}$ receptors) are beneficial for treatment resistant schizophrenic patients. It is essential, therefore, to characterize this clinically relevant interaction in the brains of normal and psychiatric patients.

We chose to examine the $5-\mathrm{HT}_{2}$ receptor due to its greater density and neurophysiologic role in the striatum and its reported involvement in psychiatric illnesses. Furthermore, this receptor subtype has been implicated in the mechanism of action of atypical neuroleptics (Pazos et al., 1987; Peroutka, 1989; Palacios, 1990; Arora and Meltzer, 1991; Deutsch et al., 1991; Meltzer, 1991). Serotonergic dysfunction in schizophrenia has been suggested by studies of plasma metabolites and cerebral spinal fluid (CSF) and receptor binding in platelets and postmortem brain tissue (Mita et al., 1986; Stahl and Wets, 1987; Arora and Meltzer, 1991). Also suggestive is the therapeutic efficacy of atypical neuroleptics which have an affinity for the 5- $\mathrm{HT}_{2}$ receptor (e.g., ritanserin), in addition to traditional neuroleptics which have some affinity for the cortical 5-HT 2 receptor (Leysen et al., 1978; Peroutka and Snyder, 1980; Deutsch et al., 1991; Meltzer, 1991). For these studies, we selected 5-HT selective drugs (whose pharmacologic profile is well known) that are used therapeutically to treat psychiatric illnesses in order to simultaneously examine their effects on " $\mathrm{C}$-raclopride binding and striatal DA release.

Altanserin, a relatively new $5-\mathrm{HT}$, receptor antagonist, is structurally related to ketanserin (Lemaire et al., 1988). It has recently been radiolabeled with fluorine-18, and appears to be more selective for the $5-\mathrm{HT}_{2}$ receptor $\left(K_{i}=0.13 \mathrm{nM}\right)$ than other PET radiotracers (Frost, 1990; Lemaire et al., 1991). However, due to its affinity for the DA $D_{2}$ receptor $\left(K_{i}=62 \mathrm{nM}\right)$ and the $\alpha_{1}$ adrenergic receptor $\left(K_{i}=4.5 \mathrm{nM}\right)$ a second more selective $5-\mathrm{HT}_{2}$ receptor antagonist, $\mathrm{SR} 46349 \mathrm{~B}$ was chosen for study. SR 46349B (trans, 4-([3Z)3-(2-dimethylaminoethyl)oxyimino3(2-fluorophenyl)propen-1-yl]phe nol hemifumarate) is a new, potent, and highly selective $5-\mathrm{HT}_{2}$ receptor antagonist that has been radiolabeled with carbon- 11 and examined with PET (Tan et al., 1994). Recent studies demonstrate that this compound has a high affinity for the $5-\mathrm{HT}_{2}$ receptor $\left(\mathrm{IC}_{50}=5.8 \mathrm{nM}, K_{d}=\right.$ $1.14 \mathrm{nM})$ and moderate affinity for the $5-\mathrm{HT}_{1 \mathrm{C}}$ receptor $\left(\mathrm{IC}_{50}=\right.$ $120 \mathrm{nM}$ ). It has very low affinity, however, for other 5-HT, DA, adrenergic, or histaminergic receptors systems (Rinaldi-Carmona et al., 1992). To confirm our findings with these two drugs, a separate group of studies was performed using citalopram, a 5-HT selective reuptake inhibitor (SSRI) which is the most selective and potent inhibitor of the 5-HT reuptake site $\left(K_{i}=2.6\right.$ $\mathrm{nM})$ presently available. It has a higher potency ratio of DA to 5-HT and norepinephrine to 5-HT, than other SSRI's (i.e., paroxetine, fluoxetine, sertraline, quipazine, 6-nitroquipazine; $\mathrm{Hy}$ tell et al., 1977, 1982; Langer et al., 1980; Koe et al., 1983; Thomas et al., 1987; Hashimoto and Goromaru, 1990; Johnson, 1993). The SSRI's, particularly citalopram, have very weak affinities for neurotransmitter receptors, especially when compared with the tricyclic antidepressants and should produce the opposite effect of a 5-HT antagonist as it causes an increase in synaptic concentrations of 5-HT.

In this study, we pretreated baboons with either altanserin or citalopram and examined their effects on the striatal and cerebellar binding of " $\mathrm{C}$-raclopride. " $\mathrm{C}$-Raclopride is a radiotracer with high selectivity and moderate affinity for the $D A D_{2}$ receptor and is sensitive to changes in endogenous DA concentrations (Young et al., 1991; Dewey et al., 1993a). Furthermore, raclopride also binds to the $D_{3}$ and $D_{4}$ receptor subtypes. Additionally, to aid in the interpretation of our PET data and to simultaneously investigate the effects that general anesthesia has on these interactions, we performed in vivo microdialysis studies in freely moving rats using the same compounds, plus the new $5-\mathrm{HT}_{2}$ receptor antagonist, SR 46349B.

An abstract of these findings has appeared previously (Dewey et al., 1992a).

\section{Materials and Methods}

Primate PET studies. Adult female baboons (Papio anubis, 13-18 kg) were used for all PET studies and labeled raclopride was synthesized as detailed previously (Farde et al., 1986). Arterial blood samples were obtained throughout the study and selected plasma samples were analyzed for the presence of unchanged radiotracer. Altanserin $(n=3)$ was administered $(2.5 \mathrm{cc})$ at a dose of $1.0 \mathrm{mg} / \mathrm{kg} 45 \mathrm{~min}$ prior to radiotracer administration. Citalopram $(n=3)$ was administered $(2.5 \mathrm{cc})$ at a dose of $1.0 \mathrm{mg} / \mathrm{kg} 180 \mathrm{~min}$ prior to radiotracer administration. Vital signs were monitored throughout the length of study using a Spacelabs monitor (model 90303B).

In vivo microdialysis measurements of extracellular DA in freely moving rats. Adult male Sprague-Dawley rats (200-300 gm, Taconic Farms) were anesthetized and siliconized guide cannulae were stereotaxically implanted into the right anterio-lateral striatum $(0.5 \mathrm{~mm}$ anterior and $2.5 \mathrm{~mm}$ lateral to bregma, and $2.5 \mathrm{~mm}$ ventral to the cortical surface) under chloral hydrate anesthesia $(400 \mathrm{mg} / \mathrm{kg}$, i.p.) at least $3 \mathrm{~d}$ prior to study. On the day of study, rats were placed in a bowl for at least 30 min prior to fraction collection. Microdialysis probes $(4.0 \mathrm{~mm}$, Bioanalytical Systems, BAS) were positioned within the guide cannulae and artificial cerebral spinal fluid (ACSF, $155.0 \mathrm{~mm} \mathrm{Na}+1.1 \mathrm{mM} \mathrm{Ca}^{2+}, 2.9$ $\mathrm{mM} \mathrm{K}+, 132.76 \mathrm{mM} \mathrm{Cl}^{-}$, and $0.83 \mathrm{mM} \mathrm{Mg}^{2+}, \mathrm{pH} \mathrm{7.4)}$ was administered through the probe using a CMA/100 microinfusion pump (BAS) at a flow rate of $2.0 \mu \mathrm{l} / \mathrm{min}$. Twenty minute samples were collected within the injection loop $(50 \mu \mathrm{l})$, injected on line (CMA $160, \mathrm{~B} \Lambda \mathrm{S})$ and analyzed until three sequential injections differed by less than $10 \%$. The average DA concentration of these three stable samples was defined as control $(100 \%)$ and all subsequent treatment values were transformed to a percentage of that control. Upon establishing this baseline measurement, altanserin $(20 \mathrm{mg} / \mathrm{kg}, 1.0 \mathrm{cc}, n=4)$, citalopram $(20 \mathrm{mg} / \mathrm{kg}, 1.0 \mathrm{cc}, n=$ 4 ), or SR $46349 \mathrm{~B}(10 \mathrm{mg} / \mathrm{kg}, 1.0 \mathrm{cc}, n=4)$, dissolved in sterile physiologic saline, was injected intraperitoneally. Control animals received saline injections using a similar injection protocol $(n=10)$. The HPLC system consists of a BAS reverse phase column $(3.0 \mu \mathrm{C}-18)$, a BAS LC-4C electrochemical transducer with a dual glassy carbon electrode set at $650 \mathrm{mV}$, and a dual pen chart recorder. The mobile phase (flow rate $=1.0 \mathrm{ml} / \mathrm{min}$ ) consisted of $9.5 \%$ methanol, $50 \mathrm{~mm}$ sodium phosphate monobasic, $1.0 \mathrm{~mm}$ sodium octyl sulfate, and $0.1 \mathrm{~mm}$ EDTA, $\mathrm{pH}$ 4.0. DA eluted at $7.5 \mathrm{~min}$. Upon completion of the study, rats were sacrificed and brains were sectioned to verify probe placement.

PET data analysis and region of interest selection. Regions of interest (ROIs) were drawn directly on the PET images using computer software supplied with the tomograph as detailed previously (Dewey et al., 1992b, 1993a). ROIs were appropriate in size for the resolution of the tomograph. Briefly, the corpus striatum was outlined, bilaterally, on every transaxial slice upon which it appeared. The cerebellar ROI was drawn across the midline at the level of the cerebellar vermis. ROIs from the first study were then copied directly onto the corresponding slice from the second. By examining placement of the ROI's on the second scan changes could be made, if necessary, in ROI position only. This multiplanar method of analysis reduces differences that may arise due to movement of the animal within the gantry during the scanning interval (Bendriem et al., 1991).

Receptor availability as a function of alterations in synaptic DA concentrations was analyzed using a graphical technique designed specifcally for reversible systems as detailed previously (Logan et al., 1990, 1994; Dewey et al., 1992b, 1993a). This analysis directly gives the steady state distribution volume (DV) which is a linear function of the free receptor concentration (Logan et al., 1990; Koeppe et al., 1991). More importantly, studies with "C-flumazenil, a reversible benzodiazepine antagonist, have recently shown that the use of the DV makes it possible to separate high-affinity binding from altered radioligand delivery due to changes in regional cerebral blood flow (Holthoff et al., 1991). We 

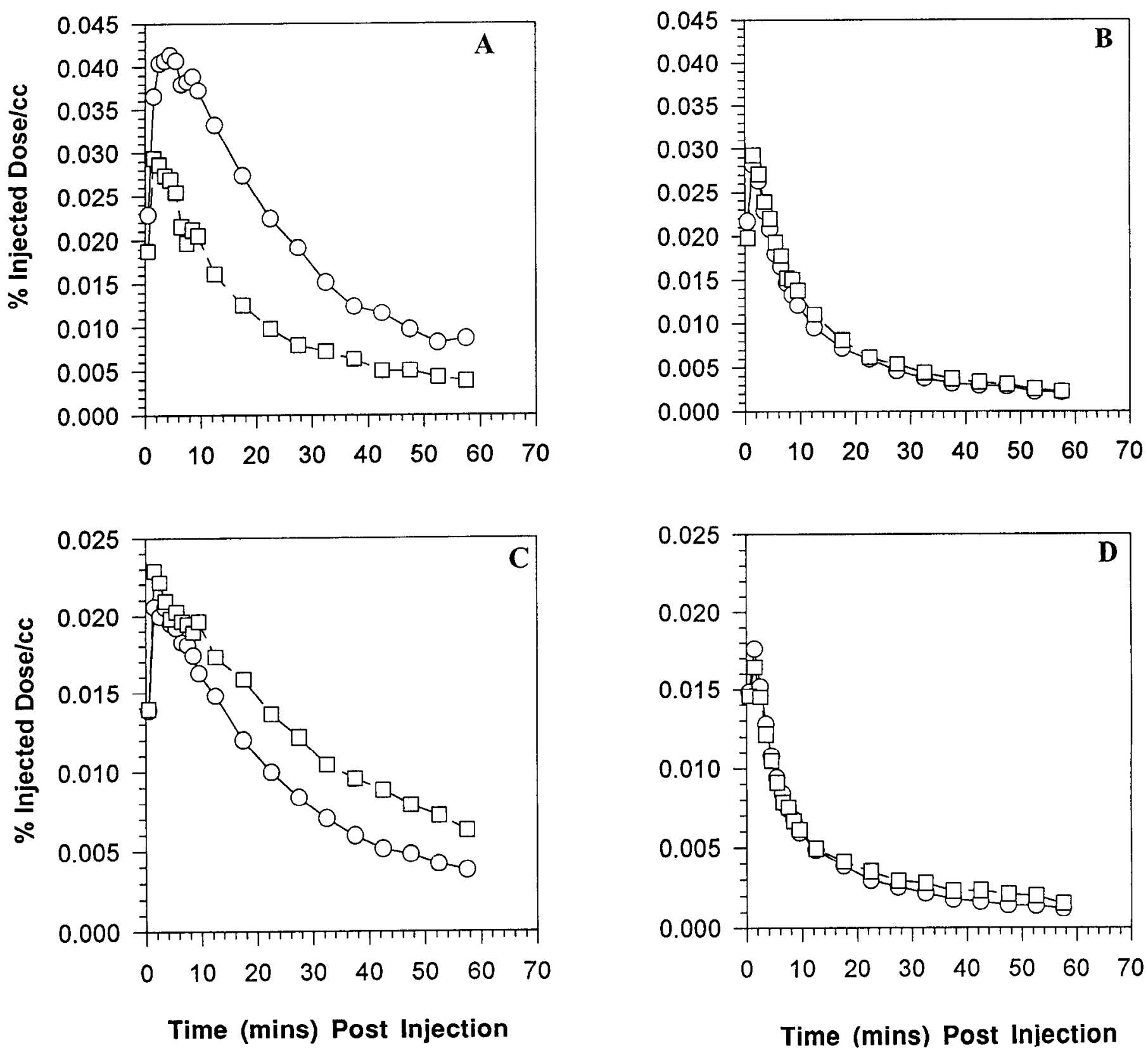

Time (mins) Post Injection

Figure 1. A, "C-Raclopride striatal time-activity data from study BE197. Open circles are from the baseline scan. Open boxes arc from the scan performed following altanserin administration. $B$, "C-Raclopride cerebellar time-activity data from study BE197. Open circles are from the baseline scan. Open boxes are from the scan performed following altanserin administration. Note that altanserin reduced striatal uptake and had no effect on cerebellar binding. $C$, "C-Raclopride striatal time-activity data from study BE265. Open circles are from the baseline scan. Open boxes are from the scan performed following citalopram administration. $D,{ }^{11} \mathrm{C}$-Raclopride cerebellar time-activity data from study BE265. Open circles are from the baseline scan. Open boxes are from the scan performed following citalopram administration. Note that citalopram increased striatal uptake and had no effect on cerebellar binding.

have presented our results for the ratio of the striatum to the cerebellum as this ratio does not contain the term $\mathrm{K} 1 / \mathrm{k} 2$ (transport constants).

\section{Results}

\section{Primate PET studies}

In all studies, there was no need to alter the placement of the ROI's from one scan to the next. Accumulation of radioactivity began immediately following radiotracer injection in both cortical and subcortical structures. With the cxception of the corpus striatum, radioactivity cleared within the first $3 \mathrm{~min}$ from cor- tical and thalamic structures and reached $50 \%$ of the peak within $5 \mathrm{~min}$. Striatal radioactivity continued to accumulate and reached a peak value within $5 \mathrm{~min}$ and cleared to $50 \%$ of the peak within 25 min. Altanserin produced a decrease in striatal "C-raclopride binding (Fig. $1 A$ ) and an average decrease in the ratio of striatal (ST) to the cerebellar (CB) DV of $37 \%$ (Table 1, Fig. 2).

Citalopram, however, produced an increase in striatal ${ }^{11} \mathrm{C}$ raclopride binding (Fig. $1 C$ ) and an average increase in the DV ratio of $33 \%$ (Table 2, Fig. 3). Neither altanserin or citalopram altered cerebellar radioactivity (Fig. $1 B, D$ ) or the systemic rate 


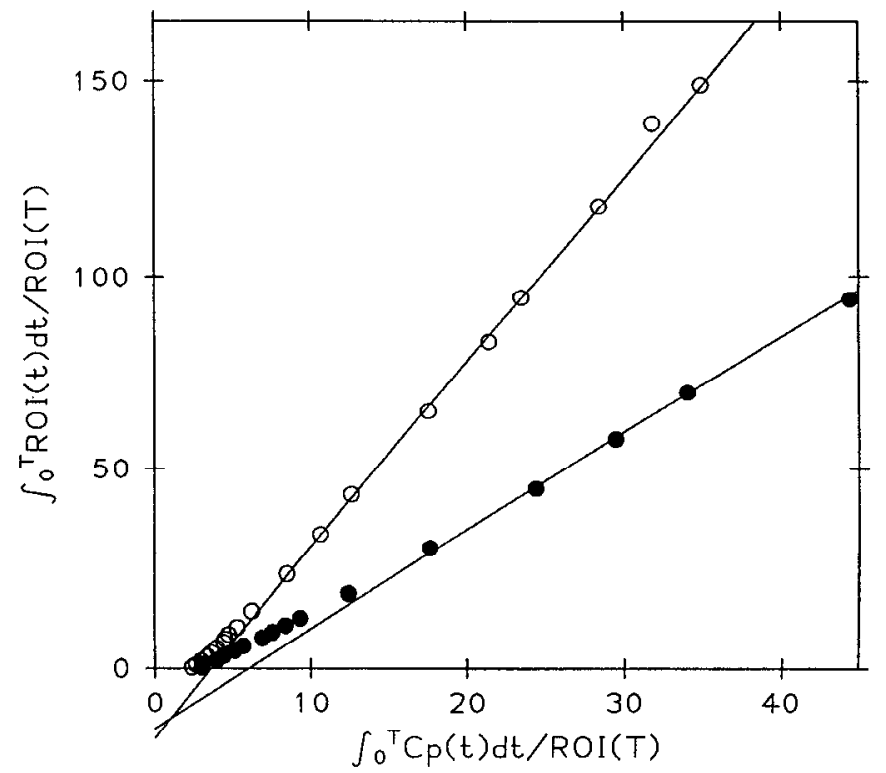

Figure 2. Logan plots of the striatal distribution volume from study BE197. Open circles are from the baseline scan. Solid circles are from the scan performed following altanserin administration.

of labeled raclopride metabolism and the metabolite corrected plasma input function.

The statistical analysis was designed to test the hypothesis that (1) the altanserin and citalopram challenge differed from the test/retest variability of this radiotracer (performed in the same animals under identical experimental conditions; Dewey et al., 1993a) and (2) the challenge conditions differed from each other. To reduce the number of comparisons and to take into account the baseline condition, difference scores were computed for the striatum, cerebellum, and the striatum to cerebellum ratio, using the formula (Study 1 - Study 2)/Study 1 . The difference scores were subjected to a univariate analysis of variance, with condition (test/retest, altanserin, citalopram; three levels) as a between-subject factor. The Scheffe test was selected as the most conservative multiple comparison test. A significant between group effect was obtained for the striatum $(F=46.25$, $p=<0.001)$, and the striatum to cerebellum ratio $(F=56.13$, $p<0.001)$, but not for the cerebellum $(F=2.94, p=0.10)$. The results of the Scheffe test for the three groups indicated that both the altanserin and citalopram conditions were significantly different from the test/retest condition, as well as from each other. The fact that significant results were obtained for the striatum and striatum to cerebellum ratio, but not for the cerebellum, indicates that the effects of the intervention were limited to the specific, but not the nonspecific binding component.

Labeled raclopride did not accumulate in any white matter

Table 1. Effects of altanserin on striatal "C-raclopride binding

\begin{tabular}{llll} 
Study & $\begin{array}{l}\text { Control } \\
\text { (ST/CB) }\end{array}$ & $\begin{array}{l}\text { Altanserin } \\
\text { pretreatment }\end{array}$ & \% Change \\
\hline BE197 & 2.81 & 1.44 & -48.8 \\
BE198 & 3.02 & 2.10 & -30.5 \\
BE200 & 2.75 & 1.83 & -33.5 \\
\hline
\end{tabular}

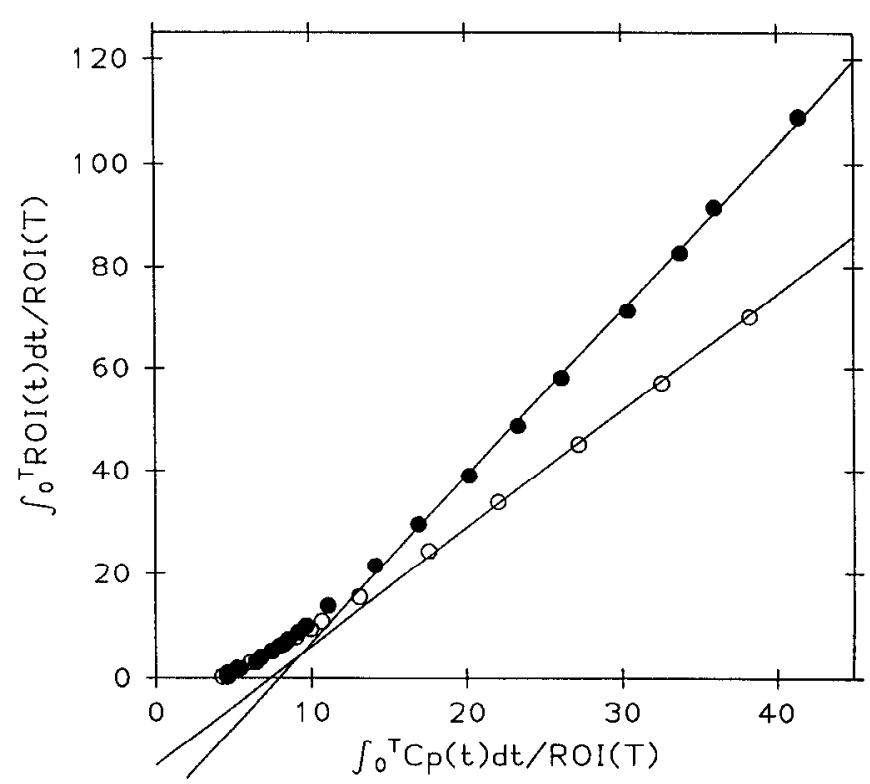

Figure 3. Logan plots of the striatal distribution volume from study BE265. Open circles are from the baseline scan. Solid circles are from the scan performed following citalopram administration.

structure and altanserin and citalopram did not alter the regional distribution of the radiotracer. Neither drug altered any vital signs during the study and in all cases, recovery from anesthesia was unremarkable.

\section{In vivo microdialysis studies}

The position of the guide cannulae within the anterior-lateral aspect of the right corpus striatum was verified in all animals. Altanserin produced an average maximum increase in extracellular striatal DA concentrations of $35 \%$ at 40 min following administration. DA concentrations returned to baseline values $60 \mathrm{~min}$ following administration and fell below baseline values for the remainder of the study (Fig. $4 A$ ). Citalopram, however, produced a gradual decrease in extracellular striatal DA concentrations that reached an average maximum of $50 \% 200 \mathrm{~min}$ following administration (Fig. 4B). SR 46349B resulted in an average maximum increase in extracellular striatal DA concentrations of $910 \% 40 \mathrm{~min}$ following administration and returned to baseline values within $120 \mathrm{~min}$ (Fig. $4 C$ ).

\section{Discussion}

The etiology and progression of many CNS diseases may result from alterations in the biochemical mechanisms that modulate and subsequently release neurotransmitters. The impetus for understanding these mechanisms is predicated not only upon the need to understand the underlying pathophysiology of these

\begin{tabular}{llll}
\hline Table 2. & Effects of citalopram on striatal "C-raclopride binding \\
& $\begin{array}{l}\text { Control } \\
\text { (ST/CB) }\end{array}$ & $\begin{array}{l}\text { Citalopram } \\
\text { pretreatment }\end{array}$ & \% Change \\
\hline Study & 2.42 & 2.91 & 20.2 \\
BE241 & 2.11 & 2.81 & 33.2 \\
BE257 & 2.11 & 3.08 & 45.9 \\
BE265 & & & \\
\hline
\end{tabular}



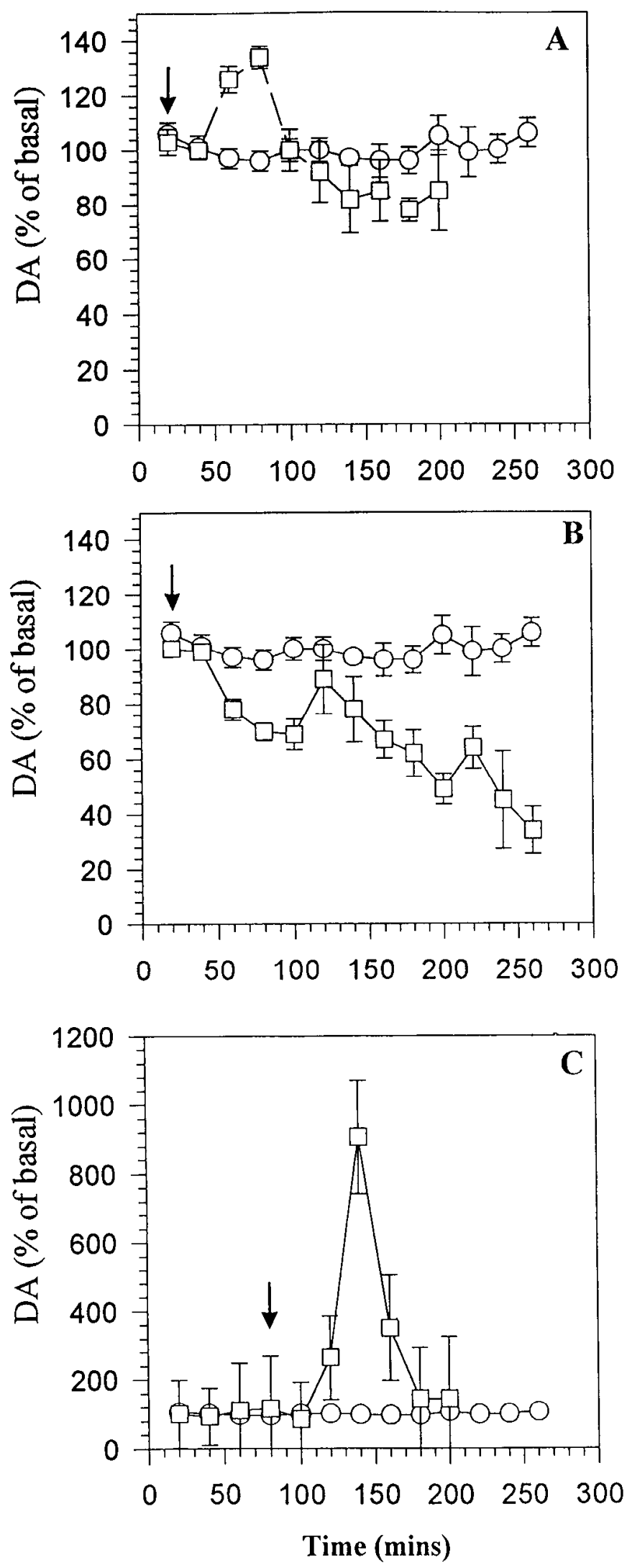

Figure 4. A, Effects of altanserin on extracellular striatal DA concentrations. Open circles are from control studies. Open squares are from studies performed following altanserin administration. $B$, Effects of citalopram on extracellular striatal DA concentrations. Open circles are from control studies. Open squares are from studies performed following diseases, but also on (1) the knowledge that many neurotransmitter-specific drugs (i.e., typical neuroleptics, anticholinergics) produce undesirable side effects which may be related to their interaction with other neurotransmitter systems, (2) the fact that many psychiatric and neurologic diseases involve multiple neurotransmitter deficits, and (3) the findings that new atypical neuroleptics beneficial for treatment resistant patients have binding affinities for more than one specific neurotransmitter system. Therefore, the therapeutic efficacy of these atypical neuroleptics may be linked to their unique ability to alter other neurotransmitter systems that are functionally linked to the target systems. PET is particularly well-suited for these studies as recent data from this laboratory demonstrates it can be used to noninvasively measure changes in neurotransmitter release following a direct or indirect neurochemically specific pharmacologic challenge.

Altanserin produced an average decrease in the ratio of DV's for ST/CB of 37\% (Table 1). In contrast, citalopram increased this ratio by an average of $33 \%$ (Table 2). The magnitude of these changes in labeled raclopride binding is similar to the effects of GBR-12909, $d$-amphetamine, and tetrabenazine, three drugs that increase striatal DA by different mechanisms (Dewey et al., 1993a). These data are consistent with 5-HT's inhibitory influence on striatal DA release as administration of a $5-\mathrm{HT}_{2}$ antagonist would disinhibit nigral DA neurons and increase striatal DA levels (Ugedo et al., 1989). Further support of this inhibitory role comes from the citalopram data as it has been shown to increase endogenous 5-HT levels (Hytell et al., 1977), resulting in a further inhibition of striatal DA release. When the second injection of " $\mathrm{C}$-raclopride was administered $60 \mathrm{~min}$ following citalopram, there was no change in the DV of the striatum or in the ratio of the ST/CB DV's (data not presented). However, when this pretreatment interval was extended to 180 min, there was a significant increase in these values. This is consistent with the microdialysis studies in that $60 \mathrm{~min}$ following citalopram, extracellular DA levels were not significantly lower than control values but by 180 min extracellular DA levels were significantly lower than controls. These studies confirm our hypothesis that citalopram decreases striatal DA concentrations. In the PET studies, this decrease in striatal DA would produce the increase in $D_{2}$ receptor occupancy by labeled raclopride observed in our primate studies. Altanserin and citalopram did not alter cerebellar binding demonstrating a regionally specific effect of these compounds on striatal DA release. These changes in ${ }^{11} \mathrm{C}$-raclopride binding significantly exceed the test/retest variability $(<10 \%)$ of this radiotracer obtained in the same animals under identical experimental conditions (Dewey et al., 1993a). As stated previously, due to the lack of selectivity of labeled raclopride for the DA receptor subtypes, it is likely that the changes in labeled raclopride binding observed following drug administration represent changes in binding to $D_{2}, D_{3}$, and $D_{4}$ receptor subtypes. However, based on mRNA levels in the striatum, $D_{3}$ and $D_{4}$ receptors are likely to be expressed at $1 / 10$ to $1 / 100$ the levels of $D_{2}$ receptors and, therefore, binding to the $D_{3}$ and $D_{4}$ receptor represents a minor contribution to citalopram administration. $C$, Effects of SR 46349B on extracellular striatal DA concentrations. Open circles are from control studies. Open squares are from studies performed following SR 46349B administration. Arrows indicate the time drugs were administered. 
the radioactivity measured in striatal PET image (Bunzow et al., 1988; Sokoloff et al., 1990; Van Tol et al., 1991).

The temporal effects of altanserin and SR 46349B on extracellular DA are different from citalopram suggesting possible differences between these compounds in their bioavailability. Altanserin and SR 46349B produced a significant incrcasc in extracellular DA concentrations $20 \mathrm{~min}$ following administration (Fig. $4 A, C$ ). Sixty min following altanserin administration DA levels returned to and fell below baseline values for the remainder of the studies. Citalopram, however, caused a gradual decrease in DA that plateaued 200 min following administration (Fig. 4B). A direct comparison of the pharmacokinetic effects of these drugs between the two techniques must be made with caution. While the microdialysis findings support the direction of changes measured with PET, it must be noted that the intravenous route of administration for the PET studies should produce higher plasma levels sooner than the intraperitoneal route used for the microdialysis experiments. The large difference in the magnitude of the effect of altanserin and SR 46349B on extracellular striatal DA levels ( $35 \%$ vs $910 \%$, respectively) may result from differences in bioavailability which could be influenced by alterations in the amount of drug that is absorbed through the gastrointestinal tract, in the rate of systemic metabolism of each compound, and in the amount of each drug that crosses the blood brain barrier and successfully enters the CNS. For example, PET studies using " $\mathrm{C}$-benztropine and ${ }^{11} \mathrm{C}$ scopolamine, two radiotracers specific for the muscarinic/cholinergic system, demonstrate that while both compounds bind to $M_{1}$ and $M_{2}$ receptors and enter the human brain in similar concentrations (Dewey et al., 1990b; Frey et al., 1992), benztropine is systematically metabolized much slower than labeled scopolamine, consistent with the longer half-life of the former. Additionally, due to altanserin's affinity for the $\mathrm{D}_{2}$ receptor $\left(K_{i}\right.$ $=62 \mathrm{nM}$ ), it could potentially bind to the presynaptic DA autoreceptor resulting in an attenuated response. Consequently, it is also possible that altanserin-induced decreases in striatal " $\mathrm{C}$ raclopride binding are due, in part, to a direct competition between altanserin and labeled raclopride for the $D_{A} D_{2}$ receptor. However, in light of our findings with citalopram and SR 46349B, it is unlikely that this explains these findings exclusively. Furthermore, pretreatment with either halopemide or bromolisuride, compounds with a much higher affinity for $D_{2}$ receptors than altanserin, did not alter ${ }^{18} \mathrm{~F}$-altanserin binding in the striatum more than the frontal cortex (Lemaire et al., 1991). Finally, altanserin's cffect on striatal DA release may be effected by interactions between other systems with which it interacts (i.e., $\alpha_{1}$ adrenergic, GABA, and sigma opiates).

The PET and microdialysis results in the present study are consistent with 5-HT's inhibition of striatal DA. There is considerable neuroanatomic evidence that supports a direct connection between 5-HT and DA-containing neurons. For example, studies by Nedergaard et al. (1988) have demonstrated that 5-HT containing terminals make direct synaptic contact with dopaminergic neurons and this interaction facilitates calcium conductance in the dendrites of these nigrostriatal neurons. Reciprocal interactions have been well characterized between the raphe nuclei and the dopaminergic cell bodies of the substantia nigra (SN) and ventral tegmental area (VTA) and the ventral striatum and nucleus accumbens (Aghajanian and Bunney, 1974; Samanin and Garattini, 1975; Dray et al., 1976; Azmitia and Segal, 1978; Herve et al., 1987; Parent et al., 1981; Van Bockstaele et al., 1993). A functional organization of mid- brain raphe nuclei has been described based upon double retrograde tract tracing studies in which neurons located more rostrally project to neostriatum, $\mathrm{SN}$, and amygdala, whereas neurons located more caudally project to the hippocampus and locus coerleus (Imai et al., 1986). 5-HT-immunoreactive nerve tcrminals have been characterized in the ventrolateral caudateputamen (Steinbusch, 1981). Major ascending 5-HT fiber systems have been described, including a transtegmental system which innervates the VTA (originating mainly from the dorsal raphe nucleus and the median raphe, to the dorsal raphe nucleus). Iontophoretically administered 5 -HT produced a slight inhibition of the firing of DA neurons in the $\mathrm{SN}$ and electrical stimulation of the raphe nucleus has been reported to inhibit and excite SN neurons as well (Dray et al., 1978). In fact, a majority of the ascending 5-HT fibers and terminals in the SN appear to be collaterals arising from the dorsal raphe nucleus (Parent et al., 1981). Finally, intermediate concentrations of $5-\mathrm{HT}_{2}$ receptors have been found in the human caudate, putamen, and globus pallidus (Luabeya et al., 1984; Beigon et al., 1986; Hoyer et al., 1986; Pazos et al., 1987). These findings have been confirmed by in situ hybridization (Mengod et al., 1990), and the concentration of thcse receptors is greater than other 5-HT receptor subtypes in the striatum (Palacios, 1990). Azmitia and Whitaker-Azmitia (1991) suggest that 5-HT plays a neurotrophic role with respect to DA. Depletion of striatal DA by the neurotoxins MPTP or 6-OHDA in neonatal or adult animals (rats and primates) results in an increase in 5-HT levels and a sprouting of serotonergic fibers in the striatum (Berger et al., 1985; Snyder et al., 1986; Luthman et al., 1987; Zhou et al., 1991). However, the functional significance of these new connections remains unclear. Saller and colleagues (1990) demonstrated that the effects of $\mathrm{D}_{2}$ dopamine blockade were modulated by ICI 169,369 a selective 5-HT 2 receptor antagonist. This compound did not, however, alter striatal $\mathrm{D}_{2}$ receptor number. Finally, it should be noted that while these findings support a role for 5-HT's ability to modulate striatal DA, the findings observed with PET may also result from 5-HT's ability to modulate other neurotransmitter systems (i.c., GABA, sigma opiates) that in turn modulate striatal DA release (Vincent et al., 1994). In fact, it is conceivable that the net effect of 5-HT on striatal DA modulation is via an inhibitory role on another neurotransmitter system that inhibits striatal DA release. The result might be a disinhibition and subsequent increase in striatal DA concentrations.

Clinical studies performed over the last decade have demonstrated the efficacy of the atypical neuroleptic, clozapine, for the treatment of schizophrenia, particularly in treatment resistant patients (Kane et al., 1988; Meltzer, 1989, 1991). The elucidation of the mechanism of action of clozapine, as distinct from more traditional neuroleptics as haloperidol, may shed light upon the etiology of the disease. At present, the hypothesis that the therapeutic efficacy of clozapine is related to its ability to block the $D_{4}$ receptor is still being evaluated. Studies are currently in progress examining the effects of a typical and an atypical neuroleptic on 5-HT/DA and DA/ACh interactions (Dewey et al., 1993c). These studies will be used to aid in the development of a method for measuring alterations in these interactions in normal human subjects, for eventual study in psychiatric illness. Assessing the functional responsiveness of a neurotransmitter to a pharmacologic challenge might serve as a predictive test for whether a given patient might respond better to a drug with a neurochemical profile similar to clozapine. The 
finding that the ACTH response to $\mathrm{mCPP}$ is greater in schizophrenic patients who respond to clozapine provides evidence for the utility of such provocative tests (Kahn et al., 1993).

Evidence from preclinical and clinical studies indicates that 5-HT receptor agonists may be useful in the treatment of extrapyramidal side effects induced by neuroleptic treatment. For example, studies of haloperidol induced catalepsy in rats have demonstrated that administration of agonists such as fenfluramine, 8-OH-DPAT, DOB, and buspirone result in a reversal of catalepsy (Neal-Belliveau et al., 1993). In addition, clozapine, remoxipride, and ritanserin have a lower propensity to induce catalepsy in rats and a lower frequency of induction of extrapyramidal side effects in patients (Meltzer et al., 1989; Mertens et al., 1990). This may be attributable to either an effect of these agents on the DA system, or on other neurotransmitters (i.e., ACh, GABA) known to be modulated by $5-\mathrm{HT}$ and related to such side effects. In addition, in the case of the atypical neuroleptics, it is unclear if this effect is attributable to either a greater potency at the $5-\mathrm{HT}_{2}$ receptor site or a lesser potency at the striatal $\mathrm{D}_{2}$ receptor site (Stockmeier et al., 1993).

5-HT/DA interactions are clinically relevant for the treatment and the study of schizophrenia and other psychiatric illnesses as the efficacy of the SSRI's (i.e., citalopram, quinpazine, 6-nitroquinpazine) may be related to the ability of these compounds to activate DA systems. Since steroid hormones modulate 5-HT and DA function (Van Hartesveldt and Joyce, 1986; Beigon, 1990), interactions between these two systems may be particularly sensitive to gender differences, as well as to fluctuations within the menstrual cycle. Furthermore, this interaction may be of interest in the study of normal aging, in that the prolactin response to fenfluramine is attenuated in normal aging, especially in females, perhaps related to a modulatory influence of estrogen (McBride et al., 1990). Finally, this use of PET has implications not only in furthering our knowledge of these neurochemical interactions and the consequences of their disruptions, but also in the area of drug design and development as it can be used to noninvasively assess the multiple mechanisms of actions of many centrally acting drugs in the living human brain.

\section{References}

Aghajanian G, Bunney B (1974) Dopaminergic and non-dopaminergic neurons of the substantia nigra: differential responses to putative transmitters. In: Proceedings of the 9th International Congress of the CINP Exerpta Medicina, Amsterdam, pp 444-452.

Arora R, Meltzer H (1991) Serotonin (5HT-2) receptor binding in the frontal cortex of schizophrenic patients. J Neural Transm 85:19-29.

Azmitia E, Segal M (1978) An autoradiographic analysis of the differential ascending projections of the dorsal and median raphe nuclei in the rat. J Comp Neurol 79:641-659.

Azmitia E, Whitaker-Azmitia A (1991) Awakening the sleeping giant anatomy and plasticity of the brain serotonergic system. J Clin Psychiatry 52:4-16.

Bendriem B, Dewey SL, Schlyer DJ, Wolf AP, Volkow ND (1991) Quantitation of the human basal ganglia with positron emission tomography: a phantom study of the effect of contrast and axial positioning. IEEE Trans Med Imaging 10:216-222.

Benloucif S, Galloway MP (1991) Facilitation of dopamine release in vivo by serotonin agonists: studies with microdialysis. Eur J Pharmacol 200:1-8.

Berger T, Kaul E, Stricker E, Zigmond M (1985) Hyperinnervation of the striatum by dorsal raphe afferents after dopamine-depleting brain lesions in neonatal rats. Brain Res 336:354-358.

Biegon A (1990) Effects of steroid hormones on the serotonergic system. Ann NY Acad Sci 600:427-434.

Biegon A, Kargman S, Snyder L, McEwen B (1986) Characterization and localization of serotonin receptors in human brain postmortem. Brain Res 363:91-96.

Bunzow J, Van Tol H, Grandy J, Albert P, Salon J, Christie M, Machida $C$, Neve K, Civelli $O$ (1988) Cloning and expression of a rat D2 dopamine receptor cDNA. Nature 251:783-787.

Castrogiovanni P, DiMuro A, Maremmani I, Perossini M, Marazziti D (1989) Interaction between the serotonin and dopamine systems in humans: preliminary findings. Brain Res 504:129-131.

Deutsch A, Moghaddam B, Innis R, Krystal J, Aghajanian G, Bunney B, Charney D (1991) Mechanisms of action of atypical antipsychotic drugs. Schizophr Res 4:121-156.

Dewey SL, Wolf AP, Fowler JS, Brodie JD, Shiue C-Y, Alavi A, Heisiger E, Schlyer DJ, Volkow ND, Raulli R, Christman D (1988) The effects of central cholinergic blockade on $\left[{ }^{18} \mathrm{~F}\right]-\mathrm{N}$-methylspiroperidol binding in the human brain using PET. XVI C.I.N.P. Congress 96: 162.

Dewey SL, Brodie JD, Fowler JS, MacGregor RR, Schlyer DJ, King PT, Alexoff DL, Volkow ND, Shiue C-Y, Wolf AP, Bendriem B (1990a) Positron emission tomography (PET) studies of dopaminergic/cholinergic interactions in the baboon brain. Synapse 6:321327.

Dewey SL, MacGregor RR, Bendriem B, King PT, Volkow ND, Schlyer DJ, Brodie JD, Fowler JS, Wolf AP, Gatley SJ, Hitzemann R (1990b) Mapping muscarinic receptors in human and baboon brain using [N${ }^{11} \mathrm{C}$-methyl]-benztropine. Synapse 5:213-223.

Dewey SL, Smith GS, Logan J, Brodie JD, King PT, Pappas N, MacGregor RR, Martin T, Alexoff D, Shea C, rowler JS, Wolf AP (1992a) Effects of serotonergic (5-HT2) blockade on endogenous dopamine release measured in vivo with positron emission tomography (PET). Soc Neurosci Abstr 18:385.7.

Dewey SL, Smith GS, Logan J, Brodie JD, Yu D-W, Ferrieri RA, King PT, MacGregor RR, Martin TP, Wolf AP, Volkow NV, Fowler JS (1992b) GABAergic inhibition of endogenous dopamine release measured in vivo with "C-raclopride and positron emission tomography. J Ncurosci 12:3773-3780.

Dewey SL, Smith GS, Logan J, Brodie JD, Fowler JS, Wolf AP (1993a) Striatal binding of the PET ligand "C-raclopride is altered by drugs that modify synaptic dopamine levels. Synapse 13:350-356.

Dewey SL, Smith GS, Logan J, Brodie JD (1993b) Modulation of central cholinergic activity by GABA and serotonin: PET studies with "C-benztropine in primates. Neuropsychopharmacology 8:371-376.

Dewey SL, Smith GS, Logan J, MacGregor RR, Brimecombe J, Kasten M, King P, Pappas N, Brodie J, Fowler J, Volkow N, Wolf AP (1993c) The effects of acute and chronic haloperidol treatment on GABAergic and serotonergic modulation of dopamine release measured with positron emission tomography (PET). Soc Neurosci Abstr 19:128.7.

Dewey SL, Smith GS, Logan J, Simkowitz P, Brodie JD, Volkow ND, Fowler JS, Wolf AP (1993d) Effects of central cholinergic blockade on striatal dopamine release measured with positron emission tomography (PET) in normal human subjects. Proc Natl Acad Sci USA 90:11816-11820.

Dray A, Gonye T, Oakley N, Tanner T (1976) Evidence for the existance of a raphe projection to the substantia nigra in the rat. Brain Res 113:45-57.

Dray A, Davies J, Oakley N, Tongroach P, Vellucci S (1978) The dorsal and medial raphe projections to the substantia nigra in the rat: electrophysiological, biochemical and behavioral observations. Brain Res 151:431-442.

Farde L, Hall H, Ehrin E, Sedvall G (1986) Quantitative analysis of dopamine-D2 receptor binding in the living human brain by positron emission tomography. Science 231:258-261.

Fibiger H, Miller J (1977) An anatomical and electrophysiologic investigation of the serotonergic projection from the dorsal raphe nucleus to the substantia nigra in the cat. Neuroscience 2:975-987.

Frey KA, Koeppe RA, Mulholland GK, Jewett D, Hichwa R, Ehrenkaufer RLE, Carey JE, Wieland DM, Kuhl DE, Agranoff BW (1992) In vivo muscarinic cholinergic receptor imaging in human brain with ["C]scopolamine and positron emission tomography. J Cereb Blood Flow Metab 12:147-154.

Frost JJ (1990) Imaging the serotonin system by positron emission tomography. Ann NY Acad Sci 600:272-281.

Hashimoto K, Goromaru T (1990) High-affinity binding of $\left[{ }^{3} \mathrm{H}\right] 6-$ nitroquipazine to 5-hydroxytryptamine transporter in human platelets. Eur J Pharmacol 187:295-302.

Herve D, Pickel V, Joh T, Beudet A (1987) Serotonin terminals in 
the ventral tegmental area of the rat: fine structure and synaptic input to dopamine neurons. Brain Res 435:7-83.

Holthoff VA, Koeppe RA, Frey KA, Paradise AH, Kuhl DE (1991) Differentiation of radioligand delivery and binding in the brain: validation of a two-compartment model for [ $\left.{ }^{11} \mathrm{C}\right]$ flumazenil. J Cereb Blood Flow Metab 11:745 - 752.

Hoyer D, Pazos A, Probst A, Palacios J (1986) Serotonin receptors in the human brain. II. Characterization and autoradiographic localization of 5-HT ${ }_{1 \mathrm{C}}$ and 5-HT, recognition sites. Brain Res 376:97-107.

Huang X, Nichols DE (1993) 5-HT2 receptor-mediated potentiation of dopamine synthesis and central serotonergic deficits. Eur J Pharmacol 238:291-296.

Hytell J (1977) Neurochemical characterization of a new potent and selective serotonin uptake inhibitor, Lu 10-171. Psychopharmacology 51:225-233.

Imai H, Stendler D, Kitai S (1986) The organization of divergent axonal projections from the midbrain raphe nuclei in the rat. J Comp Neurol 243:363-380.

Johnson A (1991) The comparative pharmacological properties of selective serotonin reuptake inhibitors in animals. In: Selective serotonin reuptake inhibitors (Feighner J, Boyner W, eds) pp 37-70. New York: Wiley.

Kahn R, Davidson M, Siever L, Gabriel S, Apter S, Davis K (1993) Serotonin function and treatment response to clozapine in schizophrenic patients. Am J Psychiatry 150:1337-1343.

Kane J, Honigfeld $G$, Singer J, Meltzer H (1988) Clozapine for the treatment resistant schiophrenic: a double blind comparison study with chlorpromaine/bentropine. Arch Gen Psychiatry 45:789-796.

Koe B, Koch S, Welch W (1983) Sertraline, a new uptake inhibitor with selectivity for serotonin. J Pharmacol Exp Ther 226:686-700.

Koeppe RA, Holthoff VA, Frey KA, Kilbourn MR, Kuhl DE (1991) Compartmental analysis of $\left[{ }^{11} \mathrm{C}\right]$ flumazenil and kinetics for the estimation of ligand transport rate and receptor distribution using positron emission tomography. J Cereb Blood Flow Metab 11:735-744.

Langer SZ, Briley MS, Raisman R, Henry J-F, Morselli PL (1980) Specific ${ }^{3} \mathrm{H}$-imipramine binding in human platelets. Naunyn-Schmiedeberg's Arch Pharmacol 313:189-194.

Lemaire C, Cantineau R, Christiaens L, Guillaume M (1988) NCA radiofluorination of altanserine a potential serotonine receptor-binding radiopharmaceutical for positron emission tomography. J Labelled Compd Radiopharm 26:336-337.

Lemaire C, Cantineau R, Guillaume M, Plenevaux A, Christiaens L (1991) Fluorine-18-Altanserin: a radioligand for the study of serotonin receptors with PET: radiolabeling and in vivo biologic behavior in rats. J Nucl Med 32:2266-2272.

Leysen J, Niemegeers C, Tollenaare J, Laduron P (1978) Serotonergic component of neuroleptic receptors. Nature 272:168-171.

Logan J, Fowler JS, Volkow ND, Wolf AP, Dewey SL, Schlyer DJ, MacGregor RR, Hitzemann R, Bendriem B, Gatley SJ, Christman DR (1990) Graphical analysis of reversible radioligand binding from time activity medsurements applied to $\left[\mathrm{N}^{-1}{ }^{11} \mathrm{C}\right.$-methyl]-(-)-cocaine PET studies in human subjects. J Cereb Blood Flow Metab 10:740-747.

Logan J, Volkow ND, Fowler J, Wang G-J, Dewey SL, MacGregor R, Schlyer D, Gatley SJ, Pappas N, King P, Hitzemann R, Vitkun S (1994) Effects of changes in blood flow on ["C]-raclopride binding in the brain: model simulations and kinetic analysis of PET data. $\mathbf{J}$ Cereb Blood Flow Metab, in press.

Luabeya M, Maloteaux J-M, Laduron P (1984) Regional and cortical laminar distributions of serotonin, benzodiazepine, muscarinic and dopamine receptor in human brain. $J$ Neurochem 43:1068-1071

Luthman J, Bolioli B, Tsutsumi T, Verhofstad A, Jonsson G (1987) Sprouting of striatal serotonin nerve terminals following selective lesions of nigro-striatal dopamine neurons in neonatal rat. Brain Res Bull 9:269-27.

McBride P, Tiemey H, DeMeo M, Chen J, Mann J (1990) Effects of age and gender on CNS serotonergic responsivity in normal adults. Biol Psychiatry 27:1143-1155.

Meltzer H (1989) Clinical studies on the mechanism of action of clozapine: the dopamine-serotonin hypothesis of schizophrenia. Psychopharmacology 99:S18-S27.

Meltzer H (1991) The mechanism of action of novel antipsychotic drugs. Schizophr Bull 17:263-287.

Mengod G, Pompeiano M, Martinez-Mir M, Palacious J (1990) Localization of the mRNA for the 5-HT2 receptor by in situ hybridiza- tion histochemistry. Correlation with the distribution of receptor sites. Brain Res 524:139-143.

Mertens C (1990) Long term treatment of chronic schizophrenic patients with risperidone. Schizophr Res 3:48.

Mita T, Hanada S, Nishino N, Kuno T, Nakai K, Yamadori T, Mioi Y, Tanaka C (1986) Decreased scrotonin S2 and increased dopamine D2 receptors in chronic schiophrenia. Biol Psychiatry 21:1407-1414.

Neal-Belliveau B, Joyce J, Lucki I (1993) Serotonergic involvement in haloperidol induced catalepsy. J Pharmacol Exp Ther 265:207217.

Nedergaard S, Bolam JP, Greenfield SA (1988) Facilitation of a dendritic calcium conductance by 5-hydroxytryptamine in the substantia nigra. Nature 333:174-176.

Palacios J (1990) Distribution of serotonin receptors. Ann NY Acad Sci 600:36-52.

Parent A, Descarries L, Beudet A (1981) Organization of ascending serotonin system in the adult brain. A radioautographic study after intraventricular administration of $\left[{ }^{3} \mathrm{H}\right] 5$-hydroxytryptamine. Neuroscience 6:15-138.

Pazos A, Probst A, Palacios J (1987) Scrotonin reccptors in the human brain-IV. Autoradiographic mapping of serotonin 2 receptors. Neuroscience 21:123-139.

Peroulka S (1989) 5-Hydroxytryptamine receptor subtypes: molecular, biochemical and physiological characterization. Trends Neurosci 11: $496-500$.

Peroutka S, Snyder S (1980) Relationship of neuroleptic drug effects at brain dopamine, serotonin, adrenergic, and histamine to clinical potency. Arch Gen Psychiatry 137:1518-1522.

Quirion R, Richard J (1985) Differential effects of selective lesions of cholinergic and dopaminergic neurons on serotonin-type 1 receptors in rat brain. Synapse 1:124-130.

Rinaldi-Carmona M, Congy C, Santucci V, Simiand J, Gautret B, Neliat G, Labeeuw B, Le Flur G, Soubrie P, Breliere JC (1992) J Pharmacol Exp Ther 262:759-768.

Samanin R, Garattini S (1975) The serotonergic system in the brain and its possible functional connections with other aminergic systems. Life Sciences 17:1201-1210.

Sinton CM, Fallon SL (1988) Electrophysiological evidence for a functional differentiation between subtypes of the 5-HT1 receptor. Eur J Pharmacol 157:173-186.

Smith GS, Dewey SL, Logan J, MacGregor RR, Brimecombe J, Kasten M, King P, Pappas N, Volkow N, Fowler J, Wolf AP (1993) Opiate modulation of striatal dopamine release measured with positron emission tomography (PET) and "C-raclopride. Soc Neurosci Abstr 19: 128.9 .

Snyder A, Zigmond M, Lund R (1986) Sprouting of serotonergic afferents into striatum after dopamine depleting lesions in infant rats. J Comp Neurol 245:274-286.

Sokoloff P, Giros B, Martres M, Bouthnet M, Schwartz J-C (1990) Molecular cloning and characterization of a novel dopamine receptor (D3) as a target for neuroleptics. Nature 347:146-151.

Sorenson SM, Humphreys TM, Palfreyman MG (1989) Effect of acute and chronic MDL 73,147EF, a 5-HT3 receptor antagonist, on A9 and AlO dopamine neurons. Eur J Pharmacol 163:115-124.

Spampinato U, Esposito E, Samanin R (1985) Serotonergic agonists reduce dopamine synthesis in the striatum only when the impulse flow of nigro-striatal neurons is intact. J Neurochem 45:980-982.

Stahl S, Wets K (1987) Indoleamines and schizophrenia. In: Handbook of schizophrenia, Vol 2 (Henn F, deLisi L, eds), pp 257-296.

Steinbusch H (1981) Distribution of serotonin immunoreactivity in the central nervous system of the rat. Neuroscience 6:557-618.

Stockmeier C, DiCarlo J, Zhang Y, Thompson P, Meltzer H (1993) Characterization of typical and atypical antipsychotic drugs based on in vivo occupancy of serotonin 2 and dopamine2 receptors. J Pharmacol Exp Ther 266:374-384.

Tan P, Dewey SL, Gatley SJ, Pappas N, MacGregor R, Ding Y-S, Shea C, Alexoff A, Martin T, Jenkins D, King P, Fowler JS, Ashby C, Wolf A (1994) Drug pharmacokinetics and pharmacodynamics: PET and microdialysis studies of SR 46349B, and selective 5-HT2 antagonist. $\mathrm{J}$ Nucl Med, in press.

Thomas D, Nelson D, Johnson A (1987) Biochemical effects of the antidepressant paroxetine, a specific 5-hydroxytryptamine uptake inhibitor. Psychopharmacology 93:193-200.

Ugedo L, Grenhoff J, Svensson TH (1989) Ritanserin, a 5-HT2 re- 
ceptor antagonist, activates midbrain dopamine neurons by blocking serotonergic inhibition. Psychopharmacology 98:45-50.

Van Bockstaele E, Biswas A, Pickel V (1993) Topography of serotonin neurons in the dorsal raphe nucleus that send axon collaterals to the rat prefrontal cortex and nucleus accumbens. Brain Res 624:188-198.

Van Hartesveldt C, Joyce JN (1986) Effects of estrogen on the basal ganglia. Neurosci Biobehav Rev 10:1-14

Van Tol H, Bunzow J, Guan $\mathbf{H}$, Sunahara $R$, Seeman P, Niznik $H$, Civelli O (1991) Cloning of the gene for the human dopamine D4 receptor with high affinity for the antipsychotic drug clozapine. Nature 350:610-614

Vincent SL, Adamec E, Sorensen I, Benes FM (1994) The effects of chronic haloperidol administration on GABA-immunoreactive axon terminals in rat medial prefrontal cortex. Synapse 17:26-35.
Waldmeier P (1980) Serotonin modulation of mesolimbic dopamine systems. Experientia 36:1092-1094.

Waldmeier P, Delini-Stula A (1979) Serotonin-dopamine interactions in the nigrostriatal system. Eur J Pharmacol 55:363-373.

Young LT, Wong DF, Goldman S, Minkin E, Chen C, Matsumura K, Scheffel U, Wagner HN (1991) Effects of endogenous dopamine on kinetics of $\left[{ }^{3} \mathrm{H}\right] \mathrm{N}$-methylspiroperidol and $\left[{ }^{3} \mathrm{H}\right]$ raclopride binding in the rat brain. Synapse 9:188-194.

Zhou F, Bledsoe S, Murphy J (1991) Serotonergic sprouting is induced by dopamine lesions in substantia nigra of adult rats. Brain Res 556: 108-116. 